Michael Friedrich · Bernhard Schink

\title{
Electron transport phosphorylation driven by glyoxylate respiration with hydrogen as electron donor in membrane vesicles of a glyoxylate-fermenting bacterium
}

Received: 19 September 1994 / Accepted: 21 December 1994

\begin{abstract}
The syntrophically glycolate-fermenting bacterium in the methanogenic binary coculture FlGlyM was isolated in pure culture (strain FlGlyR) with glyoxylate as sole substrate. This strain disproportionated 12 glyoxylate to 7 glycolate, $10 \mathrm{CO}_{2}$, and 3 hydrogen. Glyoxylate was oxidized via the malyl-CoA pathway. All enzymes of this pathway, i.e. malyl-CoA lyase/malate: CoA ligase, malic enzyme, and pyruvate synthase, were demonstrated in cell-free extracts. Glycolate dehydrogenase, hydrogenase, and ATPase, as well as menaquinones as potential electron carriers, were present in the membranes. Everted membrane vesicles catalyzed hydrogen-dependent glyoxylate reduction to glycolate [86-207 $\mathrm{nmol} \mathrm{min}^{-1}$ (mg protein $)^{-1}$ ] coupled to ATP synthesis from ADP and $\mathrm{P}_{\mathrm{i}}$

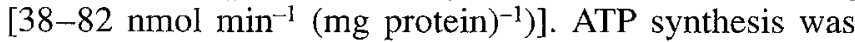
abolished entirely by protonophores or ATPase inhibitors (up to 98 and $94 \%$ inhibition, respectively) indicating the involvement of proton-motive force in an electron transport phosphorylation driven by a new glyoxylate respiration with hydrogen as electron donor. Measured reaction rates in vesicle preparations revealed a stoichiometry of ATP formation of $0.2-0.5$ ATP per glyoxylate reduced.
\end{abstract}

Key words Electron transport phosphorylation . Respiration - Membrane vesicles - Anaerobic degradation . Glyoxylate $\cdot$ Glycolate $\cdot$ Hydrogen $\cdot$ Syntrophy
Abbreviations BES 2-Bromoethanesulfonate . $C C C P$ Carbonylcyanide $m$-chlorophenylhydrazone . $D C C D N, N^{\prime}$-Dicyclohexylcarbodiimide $\cdot D C P I P$ 2,6-Dichlorophenolindophenol - DTE Dithioerythritol * TCS 3,5,4',5'-Tetrachlorosalicylanilide · SF 6847 3,5-Di-tert-butyl-4-hydroxybenzylidenemalonitrile

M. Friedrich (区) - B. Schink

Fakultät für Biologie, Universität Konstanz, Postfach 5560, D-78434 Konstanz, Germany Tel. +49-7531-88-3557; Fax + 49-7531-88-2966 e-mail michael.friedrich@uni-konstanz.de

\section{Introduction}

A defined syntrophic coculture, strain FIGlyM consisting of a gram-positive, spore-forming rod and Methanospirillum hungatei strain SK, ferments glycolate stoichiometrically to methane and $\mathrm{CO}_{2}$ (Friedrich et al. 1991). Oxidation of glycolate to $2 \mathrm{CO}_{2}+3 \mathrm{H}_{2}$, as carried out by the fermenting bacterium in the coculture, is an endergonic reaction under standard conditions $\left(\Delta \mathrm{G}^{\circ}=+36 \mathrm{~kJ} / \mathrm{mol}\right.$ glycolate). Therefore, the $\mathrm{P}_{\mathrm{H}_{2}}$ has to be kept low by a hydrogenscavening partner (e.g., a methanogenic bacterium) to support growth. Only glycolate is utilized by the fermentig bacterium, and thus growth is possible only in coculture with a hydrogen-consuming partner.

All enzymes necessary to metabolize glycolate have been detected in cell-free extracts of glycolate-grown cells of the glycolate-fermenting bacterium (Friedrich et al. 1991; Friedrich and Schink 1993). The degradation pathway includes oxidation of glycolate to glyoxylate, condensation of glyoxylate with acetyl-CoA to malylCoA, ATP formation via substrate level phosphorylation using the energy-rich thioester bond of malyl-CoA, and oxidative decarboxylation of malate to pyruvate and of pyruvate to acetyl-CoA, thus regenerating the glyoxylate acceptor for a new reaction cycle. Electrons from oxidation reactions are released as molecular hydrogen. Direct proton reduction $\left(\mathrm{E}^{\circ}=-414 \mathrm{mV}\right)$ with electrons from glycolate oxidation $\left(\mathrm{E}^{\circ}=-92 \mathrm{mV}\right.$ ) is in thermodynamic equilibrium with a $\mathrm{P}_{\mathrm{H}_{2}}$ of $1 \mu \mathrm{Pa}$, which cannot be maintained by the syntrophic partner. Therefore, a reversed electron transport is required to drive this reaction. Glycolate dehydrogenase, hydrogenase, and ATPase have been shown to be involved in proton gradient-dependent hydrogen formation from glycolate in membrane vesicles of the glycolate-fermenting bacterium, thus providing direct proof for such a reversed electron transport (Friedrich and Schink 1993). The electron carriers involved in electron transport could not be proven directly, but membranes of the glycolate-fermenting bacterium contain menaquinones as potential electron carriers (Friedrich and Schink 1993). 
This investigation reports on the isolation of the glycolate-fermenting bacterium in pure culture with glyoxylate as sole growth substrate and the metabolism of glyoxylate. Glyoxylate respiration with hydrogen as electron donor is described as a new type of anaerobic respiration.

\section{Materials and methods}

Organisms and cultivation

Strain FlGlyM (DSM 6945) was from our own culture collection. Methanospirillum hungatei strain SK was obtained from Prof. F. Widdel, Bremen, Germany. Bacteria were grown in a bicarbonatebuffered freshwater medium as described earlier (Friedrich et al. 1991 ), reduced with either $1 \mathrm{mM} \mathrm{Na}_{2} \mathrm{~S}$ or $2 \mathrm{mM}$ cysteine. For isolation, the agar shake dilution method was applied (Widdel and Pfennig 1984). Purity of cultures was checked microscopically after growth in mineral medium with glyoxylate $(5 \mathrm{mM})$, or in semisolid complex medium (AC-medium; Difco, Ann Arbor, Mich., USA) at normal and at fivefold diluted concentration.

Growth experiments were carried out in 120 -ml serum flasks filled with $50 \mathrm{ml}$ mineral medium under an atmosphere of $\mathrm{N}_{2} / \mathrm{CO}_{2}$ $(80: 20, v / v)$ at a temperature of $30^{\circ} \mathrm{C}$; samples were taken with syringes.

Preparation of cell-free extracts and membrane vesicles

Strain FlGlyR was grown under an atmosphere of $\mathrm{N}_{2} / \mathrm{CO}_{2}(80: 20$, $\mathrm{v} / \mathrm{v}$ ) in 1.25-1 infusion bottles filled with 11 mineral medium reduced with $2 \mathrm{mM}$ cysteine as described before (Friedrich and Schink 1993). Glyoxylate (final concentration $25 \mathrm{mM}$ ) was fed as sole growth substrate in portions of $5 \mathrm{mM}$ during growth. Cells were harvested in the late exponential growth phase, and cell-free extracts and spheroplasts were prepared as described previously (Friedrich and Schink 1993). Everted membrane vesicles were generated by passing spheroplasts four times through a French pressure cell at $43 \mathrm{MPa}$ pressure. After removal of cell debris, subcellular fractions were obtained by ultracentrifugation (Optima TL-ultracentrifuge equipped with a TLA-100.4-rotor; Beckman, München, Germany) at $417,000 \times g$ for $30 \mathrm{~min}$.

\section{Enzyme assays}

Spectrophotometric enzyme assays were performed under $\mathrm{N}_{2}$ atmosphere at $30^{\circ} \mathrm{C}$ in rubber-stoppered cuvettes as described before (Friedrich et al. 1991; Friedrich and Schink 1993).

Glycolate dehydrogenase (EC 1.1.99.14) activity was determined according to Friedrich and Schink (1993), malyl-CoA lyase (EC 4.1.3.24)/malate: CoA ligase (EC 6.2.1.9) according to Friedrich et al. (1991), malic enzyme (EC 1.1.1.40) according to Stams et al. (1984), pyrwyate synthase (EC 1.2.7.1) according to Odom and Peck (1981), and hydrogenase (EC 1.12.99.-) according to Diekert and Thauer (1978). ATPase (EC 3.6.1.34) was analyzed according to Vogel and Steinhart (1976).

Glyoxylate reductase (EC 1.1.1.26) was analyzed with $\mathrm{NAD}(\mathrm{P}) \mathrm{H}$ $\left(\varepsilon_{365 \mathrm{~nm}}=3.5\right) \mathrm{mM}^{-1} \mathrm{~cm}^{-1}$ ) as electron donor. The assay mixture contained $50 \mathrm{mM}$ potassium phosphate buffer $(\mathrm{pH} 6.5), 2.5 \mathrm{mM}$ dithioerythritol (DTE), $5 \mathrm{mM} \mathrm{MgCl}$ and $0.3 \mathrm{mM} \mathrm{NAD(P)H.} \mathrm{The}$ reaction was started either with protein or with $10 \mathrm{mM}$ glyoxylate.

$N A D(P) H$ :acceptor oxidoreductase (EC 1.6.99.1) was measured following the reduction of benzyl viologen $\left(\varepsilon_{578 \mathrm{~mm}}=8.65\right.$ $\left.\mathrm{mM}^{-1} \mathrm{~cm}^{-1}\right)$ or methylene blue $\left(\varepsilon_{570 \mathrm{~mm}}=13.1 \mathrm{mM}^{-1} \mathrm{~cm}^{-1}\right)$ with $\mathrm{NAD}(\mathrm{P}) \mathrm{H}$. The assay mixture contained $50 \mathrm{mM}$ potassium phosphate buffer ( $\mathrm{pH} 6.5$ ), $2.5 \mathrm{mM}$ DTE, $0.3 \mathrm{mM}$ NAD(P)H, and 5 $\mathrm{mM}$ benzyl viologen or $0.1 \mathrm{mM}$ methylene blue. NADPH oxidation with protons as electron acceptors was determined with the same assay mixture, but artificial electron acceptors were omitted. The reactions were started by addition of protein.
Assay for glyoxylate reduction with hydrogen

The assay was performed under an atmosphere of hydrogen $(0.15$ $\mathrm{MPa}$ ) in 5-ml glass vials sealed with butyl rubber septa and containing $50 \mathrm{mM}$ potassium phosphate buffer $(\mathrm{pH} 6.5), 2.5 \mathrm{mM}$ DTE, $5 \mathrm{mM} \mathrm{Na}$-ADP, $5 \mathrm{mM} \mathrm{MgCl}$, and $10 \mathrm{mM}$ glyoxylate. Alternatively, NADPH $(0.5 \mathrm{mM})$ was checked as electron donor for glyoxylate reduction. The reaction was started with membrane protein $(0.2-0.8 \mathrm{mg})$. Samples $(100 \mu \mathrm{l})$ were withdrawn with gastight syringes (Unimetrics; Macherey-Nagel, Diiren, Germany), placed on ice immediately, and analyzed subsequently by HPLC.

\section{DNA base composition}

The $\mathrm{G}+\mathrm{C}$ content of the DNA was determined by direct quantitation of the nucleosides with HPLC after enzymatic degradation of the DNA (Mesbah et al. 1989), using phage $\lambda$ DNA as standard, DNA was isolated from a 1-1 culture of glyoxylate-grown cells of strain FlGlyR using the NaOH method for cell disruption (Mesbah et al. 1989).

\section{Chemical analyses}

Methane and hydrogen were quantified by gas chromatography (Platen and Schink 1987; Friedrich and Schink 1993); samples containing less than $0.2 \mathrm{nmol}$ hydrogen were analyzed using a RGD2 reduction gas detector (Techmation, Düsseldorf, Germany) (Friedrich and Schink 1993).

Glycolate, glyoxylate, and formate were measured by HPLC as described previously (Friedrich et al. 1991), using an ORH-801 organic acids column $(300 \times 6.5 \mathrm{~mm}$; Interaction Chemicals, Mountain View, Calif., USA) with $5 \mathrm{mM} \mathrm{H}_{2} \mathrm{SO}_{4}$ as eluent at a flow rate of $0.6 \mathrm{ml} / \mathrm{min}$ at $50^{\circ} \mathrm{C}$. Compounds were detected by a refractive index detector (Erma, Tokyo, Japan).

ATP, ADP, and AMP were determined by HPLC employing ion-pair chromatography (Litters and Schmelzeisen-Redeker 1989). Separation was performed on an Ultrasphere-ODS column (150 $\times$ $4 \mathrm{~mm}$, Beckman, München, Germany) with $80 \mathrm{mM} \mathrm{KH}_{2} \mathrm{PO}_{4}$ (adjusted to $\mathrm{pH} 6.0$ with $1 \mathrm{M} \mathrm{KOH}$ ), and $5 \mathrm{mM}$ tetrabutylammonium hydrogen sulfate/methanol $(77: 23, \mathrm{v} / \mathrm{v})$ as eluent at a flow rate of $1.25 \mathrm{ml} / \mathrm{min}$. Adenosine derivatives were detected at $260 \mathrm{~nm}$ wavelength and analyzed as described earlier (Friedrich et al. 1991).

Protein determination

Protein was determined by the microprotein assay (Bradford 1976) with bovine serum albumin as standard.

\section{Chemicals}

All chemicals were of analytical or reagent grade quality and were obtained from Biomol, Ilvesheim, Germany; Boehringer, Mannheim, Germany; Fluka, Neu-UIm, Germany; Eastman Kodak, Rochester, N.Y., USA; Merck, Darmstadt, Germany; Serva, Heidelberg, Germany; Sigma, Deisenhofen, Germany; or WakoChemie, Neuss, Germany. Gases were purchased from MesserGriesheim (Darmstadt, Germany) and Sauerstoffwerke Friedrichshafen (Friedrichshafen, Germany).

\section{Results}

Isolation

The syntrophically glycolate-oxidizing bacterium in the binary methanogenic coculture FlGlyM was enriched with glyoxylate as sole growth substrate. Transferred sub- 
Fig. 1 Phase contrast photomicrograph of strain FlGlyR (bar $10 \mu \mathrm{m}$ )

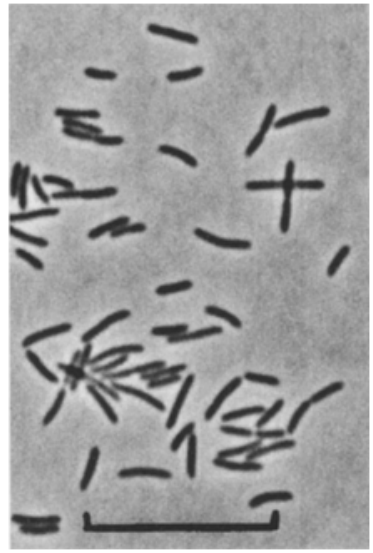

cultures resumed growth much faster in cysteine-reduced $(2 \mathrm{mM})$ mineral medium than in sulfide-reduced $(1 \mathrm{mM})$ mineral medium. In cysteine-reduced medium the coculture grew with glyoxylate as substrate if glyoxylate was added in small amounts ( $1 \mathrm{mM})$ to a coculture growing with glycolate. Transfers of glyoxylate-adapted cocultures resumed growth immediatedly, and glyoxylate could be added up to $5 \mathrm{mM}$ in one step. Attempts to isolate the fermenting bacterium from the coculture by agar shake dilution series with glyoxylate as substrate failed. Colony formation was observed only in the first tube of a dilution series, but all colonies contained $M$. hungatei. Therefore, cultures were grown in the presence of 2-bromoethanesulfonate $(2 \mathrm{mM}$; BES) to inhibit growth of $M$. hungatei. After several transfers in the presence of BES, M. hungatei was diluted out, and the fermenting bacterium grew in pure culture with glyoxylate.

Again, attempts to isolate the fermenting bacterium from the axenically grown culture by the agar dilution method failed. No colony formation was observed, even after 3 months of incubation. Purity of this culture was checked after growth with glyoxylate in AC medium, or after growth with glyoxylate in mineral medium without BES in the presence of formate as a possible growth substrate for $M$. hungatei. In all cases, $M$. hungatei was not observed microscopically, and no $\mathrm{CH}_{4}$ was formed.

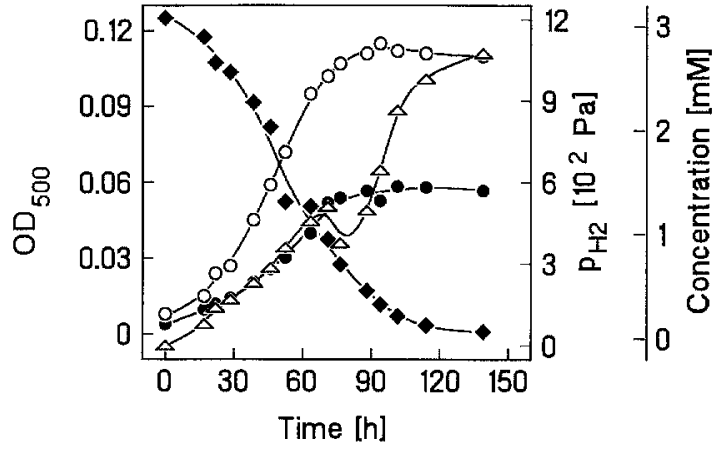

Fig. 2 Time course of glyoxylate fermentation by strain FIGlyR. $\mathrm{OD}_{500}$ (open circles), glyoxylate (filled diamonds), glycolate (filled circles), hydrogen (open triangles)

After reassociation of the glyoxylate-grown pure culture with $M$. hungatei, glycolate was degraded completely to $\mathrm{CH}_{4}$, proving that the fermenting bacterium isolated from coculture FlGlyM was identical with the glycolate-oxidizing bacterium. The strain was named FlGlyR (Fig. 1).

\section{Morphological and cytological properties} of strain FlGlyR

Cells of strain FlGlyR were gram-positive, slightly curved rods, $2.0-3.5 \times 0.45 \mu \mathrm{m}$ in size (Fig. 1). Endospore formation was observed after syntrophic growth with glycolate without delay; glyoxylate-grown cultures formed only a few spores, even after several months of incubation. Poly-( $\beta$ )-hydroxybutyrate or other inclusion bodies were not detected. The $\mathrm{G}+\mathrm{C}$ content of the DNA was $46.7 \pm$ $0.15 \mathrm{~mol} \%$.

\section{Physiology}

Strain FlGlyR oxidized glyoxylate to $\mathrm{CO}_{2}$ and $\mathrm{H}_{2}$ and reduced part of the glyoxylate to glycolate. Hydrogen accu-

Table 1 Stoichiometry of fermentation and growth yields of strain FlGlyR. Growth experiments were carried out in 120 -ml serum flasks filled with 50-60 ml mineral medium under a $\mathrm{N}_{2} / \mathrm{CO}_{2}(80: 20, \mathrm{v} / \mathrm{v})$ atmosphere

\begin{tabular}{|c|c|c|c|c|c|c|c|c|}
\hline \multirow{2}{*}{$\begin{array}{l}\text { Glyoxylate } \\
\text { concentration } \\
(\mathrm{mM})\end{array}$} & \multirow{2}{*}{$\begin{array}{l}\text { Glyoxylate } \\
\text { degraded } \\
(\mu \mathrm{mol})\end{array}$} & \multirow{2}{*}{$\begin{array}{l}\text { Optical } \\
\text { density } \\
\text { reached } \\
\Delta \mathrm{E}_{500}\end{array}$} & \multirow{2}{*}{$\begin{array}{l}\text { Cell dry } \\
\text { mass } \\
\text { formed } \\
\text { (mg) }\end{array}$} & \multirow{2}{*}{$\begin{array}{l}\text { Substrate } \\
\text { assimi- } \\
\text { lated }^{\mathbf{a}} \\
(\mu \mathrm{mol})\end{array}$} & \multicolumn{2}{|c|}{$\begin{array}{l}\text { Products formed } \\
(\mu \mathrm{mol})\end{array}$} & \multirow{2}{*}{$\begin{array}{l}\text { Electron } \\
\text { recovery } \\
(\%)\end{array}$} & \multirow{2}{*}{$\begin{array}{l}\text { Molar } \\
\text { growth } \\
\text { yield } \\
(\mathrm{g} / \mathrm{mol})\end{array}$} \\
\hline & & & & & Glycolate & $\mathbf{H}_{2}$ & & \\
\hline \multicolumn{9}{|l|}{ FlGlyR } \\
\hline 3 & 162 & 0.08 & $0.93^{b}$ & 38 & 70 & 29 & 98 & 5.7 \\
\hline 7 & 382 & 0.151 & $1.75^{\mathrm{b}}$ & 72 & 154 & 38 & 84 & 4.6 \\
\hline \multicolumn{9}{|l|}{ Per Glyox $1^{d}$} \\
\hline 10 & 512 & 0.072 & $0.92^{\mathrm{c}}$ & 38 & 140 & 547 & 103 & 1.8 \\
\hline
\end{tabular}

a Glyoxylate assimilated was calculated according to the formula: $17 \mathrm{C}_{2} \mathrm{H}_{2} \mathrm{O}_{3} \rightarrow 4<\mathrm{C}_{4} \mathrm{H}_{7} \mathrm{O}_{3}>+3 \mathrm{H}_{2} \mathrm{O}+18 \mathrm{CO}_{2}$

b, c Cell dry matter values were calculated via cell density using an experimentally determined conversion factor ( ${ }^{\mathrm{b}} 0.1 \mathrm{OD}_{500}=21 \mathrm{mg}$ dry matter; ${ }^{c} 0.1 \mathrm{OD}_{500}=25 \mathrm{mg}$ dry matter $/ \mathrm{l}$ )

d Data taken from Friedrich and Schink (1991) 
mulated up to a $\mathrm{P}_{\mathrm{H}_{2}}$ of $1,000 \mathrm{~Pa}$ (Fig. 2). The doubling time of strain FlGlyR was $33 \mathrm{~h}\left(\mu=0.021 \mathrm{~h}^{-1}\right.$; Fig. 2$)$, which was shorter than that for growth of the coculture with glycolate $\left(t_{\mathrm{d}}=51 \mathrm{~h}\right.$; Friedrich et al. 1991). If initial glyoxylate concentrations higher than $5 \mathrm{mM}$ were applied for growth, the lag phase was considerably longer or the culture did not resume growth at all. Therefore, the fermentation balance was analyzed only with low substrate concentrations (Table 1). With constant gas volume of the culture vessel, an increase in glyoxylate supply resulted in a shift of the fermentation stoichiometry towards more glycolate formation, whereas the amount of $\mathrm{H}_{2}$ formed was the same in all cases (Table 1). Cysteine acted only as reducing agent and sulfur source and was not dissimilated as the fermentation balance demonstrates (Table 1). Strain FlGlyR did not grow with glycolate in pure culture, or with other intermediates of the malyl-CoA pathway (Friedrich et al. 1991), i.e., malate or pyruvate, or with fumarate, succinate, or $\mathrm{H}_{2} / \mathrm{CO}_{2}$ in cysteine-reduced medium. No growth occurred with glyoxylate in the presence of $\mathrm{H}_{2} / \mathrm{CO}_{2}(80: 20, \mathrm{v} / \mathrm{v})$ in the gas phase.

\section{Enzymes involved in glyoxylate degradation}

Enzymes involved in glycolate degradation were detected in crude extracts of the pure culture FlGlyR at activities sufficient to account for dissimilatory turnover of glyoxylate by an exponentially growing culture $\left[136 \mathrm{nmol} \mathrm{min}^{-1}\right.$ (mg protein $\left.)^{-1}\right]$. All enzyme activities of the malyl-CoA pathway of glyoxylate degradation were detected; malylCoA lyase/malate: CoA ligase $[0.95 \mathrm{U} \text { (mg protein })^{-1}$, measured as reaction chain], malic enzyme [10.2 $\mathrm{U}(\mathrm{mg}$ protein $)^{-1}$, Table 2)], and pyruvate synthase $[0.17 \mathrm{U}$ (mg protein $)^{-1}$ ] were present at activities comparable to those found previously in crude extracts of the coculture FlGlyM grown on glycolate (Friedrich et al. 1991).

A membrane-bound glycolate dehydrogenase activity reacting with methylene blue, benzyl viologen, DCPIP, ferricyanide, and water-soluble quinones, which was found previously in cells grown syntrophically with glycolate (Friedrich and Schink 1993), was also found in glyoxylate-grown cells of the pure culture (Table 2); hydrogenase and ATPase were also present at significant activities in the membrane fraction (Table 2). Malic enzyme as a cytoplasmic marker was almost entirely recovered in the cytoplasmic fraction, indicating successful separation of both cell fractions.

ATP formation coupled to glyoxylate reduction with hydrogen in membrane vesicles

Membrane vesicle preparations of strain FlGlyR catalyzed $\mathrm{H}_{2}$-dependent glyoxylate reduction to glycolate (Fig. 3A). ATP was formed from ADP and $P_{i}$ if glyoxylate was reduced with $\mathrm{H}_{2}$ to glycolate in membrane vesicles (Fig. 3B). No ATP formation occurred if glyoxylate or hydrogen was omitted, indicating that ATP was not formed from ADP by adenylate kinase. During complete glyoxy-
Table 2 Distribution of membrane-associated enzyme activities in subcellular fractions of strain FlGlyR. Electron donors or acceptors for redox reactions are given in parentheses ( $D H$ dehydrogenase, $M B$ methylene blue, $M V$ methyl viologen)

\begin{tabular}{|c|c|c|c|c|}
\hline Enzyme activity & $\mathrm{U}$ & $\begin{array}{l}\text { Protein } \\
(\mathrm{mg})\end{array}$ & $\begin{array}{l}\text { Specific } \\
\text { activity } \\
\text { (U/mg) }\end{array}$ & $\begin{array}{l}\text { Proportion } \\
\text { in source } \\
(\%)\end{array}$ \\
\hline \multicolumn{5}{|c|}{ Glycolate DH (MB) } \\
\hline Extract & 14.9 & 15.53 & 0.96 & 100 \\
\hline Cytoplasm & 0.9 & 12.4 & 0.073 & 6 \\
\hline Membrane & 14.5 & 3.1 & 4.03 & 97 \\
\hline \multicolumn{5}{|c|}{ Hydrogenase (MB) } \\
\hline Extract & 303 & 15.53 & 19.5 & 100 \\
\hline Cytoplasm & 578 & 12.4 & 46.6 & 190 \\
\hline Membrane & 87 & 3.1 & 28.2 & 29 \\
\hline \multicolumn{5}{|c|}{ Hydrogenase (MV) } \\
\hline Extract & 71.5 & 15.53 & 4.6 & 100 \\
\hline Cytoplasm & 100 & 12.4 & 8.1 & 140 \\
\hline Membrane & 16.8 & 3.1 & 5.4 & 23 \\
\hline \multicolumn{5}{|l|}{ ATPase } \\
\hline Extract & 11.4 & 36.6 & 0.31 & 100 \\
\hline Cytoplasm & 6.8 & 21 & 0.32 & 56 \\
\hline Membrane & 4.9 & 12 & 0.41 & 43 \\
\hline \multicolumn{5}{|l|}{$\begin{array}{l}\text { Malic enzyme } \\
\left(\mathrm{NADP}^{+}\right)\end{array}$} \\
\hline Extract & 373 & 36.6 & 10.2 & 100 \\
\hline Cytoplasm & 229 & 21 & 10.9 & 61 \\
\hline Membrane & 4.5 & 12 & 0.4 & 1.2 \\
\hline
\end{tabular}

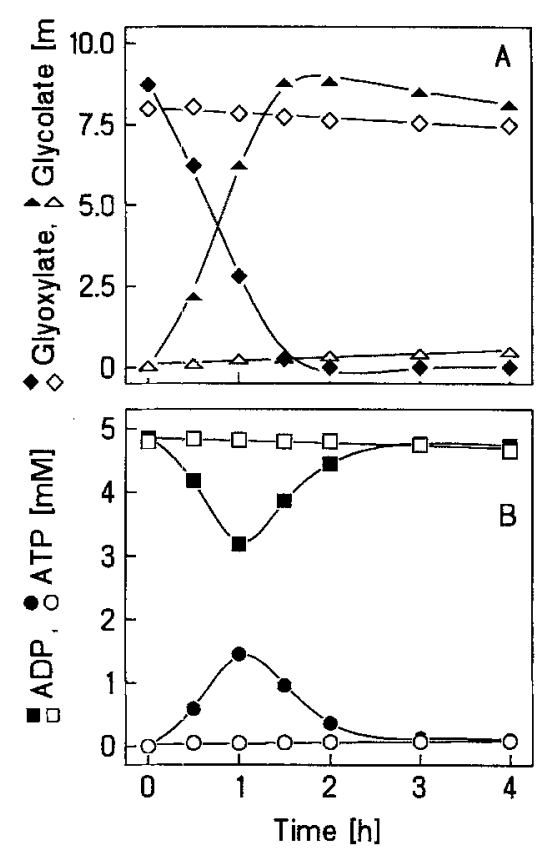

Fig. 3 Time course of glyoxylate reduction with $\mathbf{A} \mathrm{H}_{2}$ and $\mathbf{B}$ ATP formation in everted membrane vesicles of strain FlGlyR. A complete assay mixture (filled symbols) contained: $9 \mathrm{mM}$ glyoxylate, 5 mM ADP, $0.15 \mathrm{MPa} \mathrm{H}_{2}$ in the gas phase and $0.43 \mathrm{mg}$ membrane protein. As a control, $\mathrm{H}_{2}$ was omitted (open symbols). Glyoxylate (open and filled diamonds), glycolate (open and filled triangles), ADP (open and filled squares), and ATP (open and filled circles) 
late reduction to glycolate, ATP accumulated to concentrations of $1.5 \mathrm{mM}$ and was later hydrolyzed to ADP and $P_{i}$. A stoichiometry of 0.25 to 0.5 ATP per glyoxylate was deduced from rates of glyoxylate reduction with hydrogen [86-267 $\mathrm{nmol} \mathrm{min}^{-1}$ (mg protein) $\left.{ }^{-1}\right]$ versus ATP formation [38-82 $\mathrm{nmol} \mathrm{min}{ }^{-1}$ (mg protein $)^{-1}$.

At low concentrations of the protonophores tetrachlorosalicylanilide (TCS), carbonylcyanide $m$-chlorophenyl-

Table 3 Effect of protonophores and the ATPase inhibitor DCCD on $\mathrm{H}_{2}$-dependent glyoxylate reduction and on respiration-dependent ATP formation. Inhibitors dissolved in ethanol (final concentration $0.5 \%$ ) were added $20 \mathrm{~min}$ prior to the start of the reaction with glyoxylate (CCCP carbonylcyanide $m$-chlorophenyl-hydrazone, $D C C D N, N^{\prime}$-dicyclohexylcarbodiimide, $T C S$ 3,5,4',5'-tetrachlorosalicylanilide)

\begin{tabular}{|c|c|c|c|c|c|}
\hline 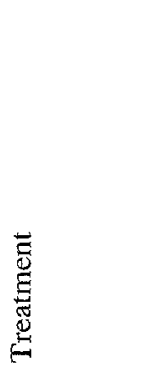 & 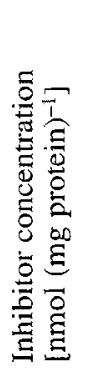 & 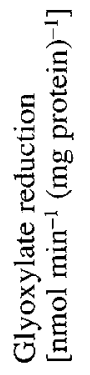 & 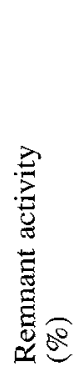 & 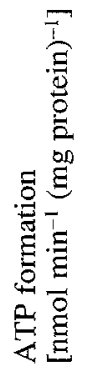 & 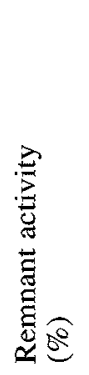 \\
\hline None & 0 & 259 & 100 & 63 & 100 \\
\hline TCS & 59 & 118 & 46 & 1.3 & 2 \\
\hline TCS & 118 & 94 & 36 & 1.3 & 2 \\
\hline DCCD & 59 & 177 & 68 & 6.7 & 11 \\
\hline DCCD & 118 & 186 & 72 & 3.9 & 6 \\
\hline None & 0 & 126 & 100 & 55 & 100 \\
\hline TCS & 0.74 & 116 & 92 & 53 & 96 \\
\hline TCS & 1.5 & 111 & 88 & 21 & 38 \\
\hline TCS & 3 & 105 & 83 & 1.7 & 3 \\
\hline TCS & 7.4 & 90 & 71 & 0.8 & 1.5 \\
\hline $\mathrm{CCCP}$ & 7.4 & 105 & 83 & 57 & 104 \\
\hline $\mathrm{CCCP}$ & 15 & 124 & 98 & 47 & 85 \\
\hline $\mathrm{CCCP}$ & 74 & 121 & 96 & 17 & 31 \\
\hline
\end{tabular}

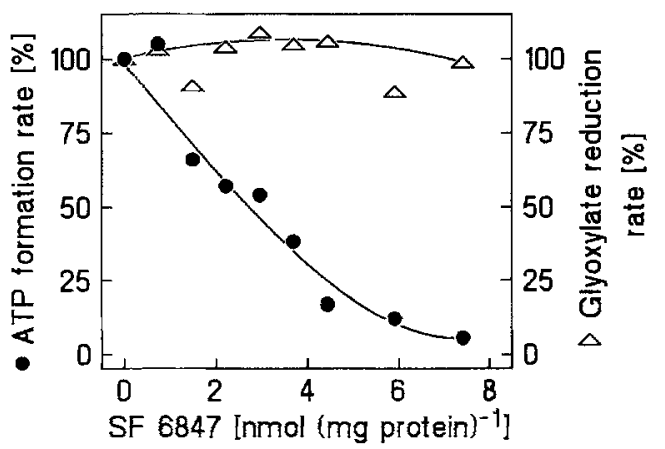

Fig. 4 Effect of the protonophore 3,5-di-tert-butyl-4-hydroxybenzylidenemalonitrile (SF 6847) on respiration-dependent ATP formation activity (filled circles) and on $\mathrm{H}_{2}$-dependent glyoxylate reduction activity (open triangles). Assay conditions were as in Fig. 3. SF 6847 dissolved in ethanol was added $20 \mathrm{~min}$ before the start of the reaction with glyoxylate and ADP. For ATP formation, $100 \%$ activity $=49 \mathrm{nmol} \mathrm{m^{-1 }}(\mathrm{mg} \text { protein })^{-1}$; for glyoxylate reduction, $100 \%$ activity $=107 \mathrm{nmol} \mathrm{min}^{-1}(\mathrm{mg} \text { protein })^{-1}$ hydrazone (CCCP), and 3,5-di-tert-butyl-4-hydroxybenzylidene malonitrile (SF 6847) ATP formation was uncoupled from glyoxylate reduction entirely (Table 3; Fig. 4). As shown by inhibitor titration, SF 6847 inhibited ATP formation almost completely at a concentration of 7.4 $\mathrm{nmol}$ (mg protein) $)^{-1}$ with a remnant ATP formation rate of

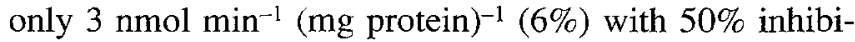
tion at $3 \mathrm{nmol}$ (mg protein) ${ }^{-1}$ (Fig. 4). CCCP inhibited ATP formation at comparably higher concentrations ( $31 \%$ remnant activity at $\left.74 \mathrm{nmol}(\mathrm{mg} \text { protein })^{-1}\right)$. Neither protonophore affected the rate of glyoxylate reduction with hydrogen at all. TCS also uncoupled ATP formation from glyoxylate respiration very effectively at low concentrations up to $7.4 \mathrm{nmol}$ (mg protein) ${ }^{-1}$, whereas glyoxylate respiration was affected only up to $30 \%$ (Table 3 ). At higher concentrations of up to $118 \mathrm{nmol}$ (mg protein) ${ }^{-1}$, the effect of TCS on glyoxylate reduction was more pronounced with an inhibition of up to $66 \%$ (Table 3 ).

The ATPase inhibitor dicyclohexylcarbodiimide (DCCD; Linnett and Beechey 1979; Hassinen and Vuokila 1993) uncoupled ATP formation driven by $\mathrm{H}_{2}$-dependent glyoxylate reduction almost entirely $(94 \%)$ at a DCCD concentration of $118 \mathrm{nmol}(\mathrm{mg} \text { protein })^{-1}$, whereas glyoxylate reduction to glycolate was affected only to a minor extent with a remnant activity of $72 \%$ (Table 3 ); glycolate dehydrogenase and hydrogenase activity were insensitive to the applied inhibitors, and the ATPase activity in strain FlGlyR was inhibited by DCCD, as proven previously (Friedrich and Schink 1993). These results indicate that the proton-motive force is involved in ATP formation.

\section{$\mathrm{H}_{2}$-dependent $\mathrm{NADP}^{+}$reduction}

During glyoxylate oxidation, electrons are transferred to a ferredoxin-like carrier in the pyruvate synthase $\left(\mathrm{E}^{\circ}=\right.$ $-470 \mathrm{mV}$ ) and to $\mathrm{NADP}^{+}$in the malic enzyme reaction $\left(\mathrm{E}^{\circ}=-331 \mathrm{mV}\right)$. The pure culture releases part of them, preferentially the former ones, as $\mathrm{H}_{2}\left(\mathrm{E}^{\circ}=-414 \mathrm{mV}\right)$, and the remainder is used up in glyoxylate reduction to glycolate.

Membranes and cytoplasmic fractions oxidized NADPH with benzyl viologen and methylene blue, but not with protons as electron acceptors (Table 4). Instead, high activities of $\mathrm{H}_{2}$-dependent $\mathrm{NADP}^{+}$reduction were found in both fractions (Table 4), indicating that the metabolism of NADPH is partly associated with the cytoplasmic membrane. However, no ADP phosphorylation driven by $\mathrm{H}_{2}-$ dependent $\mathrm{NADP}^{+}$reduction was detected. A small, apparently glyoxylate-dependent, NADPH-oxidizing activity was found exclusively in the membrane fraction as determined by photometric assay of NADPH oxidation (Table 4). However, this reaction could not be verified in a discontinuous HPLC assay monitoring glyoxylate conversion to glycolate. 
Table 4 Distribution of substrate-converting activities in $\mathrm{NADP}(\mathrm{H})$ metabolism in subcellular fractions of strain FlGlyR ( $B V$ benzyl viologen, $M B$ methylene blue)

\begin{tabular}{|c|c|c|c|c|c|c|}
\hline Activity & $\begin{array}{l}\text { Electron } \\
\text { acceptor/ } \\
\text { donor }\end{array}$ & Source & $\begin{array}{l}\text { Activity } \\
\text { (U) }\end{array}$ & $\begin{array}{l}\text { Protein } \\
\text { (mg) }\end{array}$ & $\begin{array}{l}\text { Specific } \\
\text { activity } \\
\text { (U/mg) }\end{array}$ & $\begin{array}{l}\text { Proportion } \\
\text { in source } \\
(\%)\end{array}$ \\
\hline \multirow{3}{*}{$\begin{array}{l}\text { Glyoxylate } \\
\text { reduction }\end{array}$} & \multirow[t]{3}{*}{ NADPH } & Extract & 0.52 & 22.7 & 0.023 & 100 \\
\hline & & Cytoplasm & 0 & 15.3 & 0 & 0 \\
\hline & & Membrane & 0.62 & 3.1 & 0.2 & 119 \\
\hline \multirow{9}{*}{$\begin{array}{l}\text { NADPH } \\
\text { oxidation }\end{array}$} & \multirow[t]{3}{*}{$\mathrm{BV}$} & Extract & 29.5 & 22.7 & 1.3 & 100 \\
\hline & & Cytoplasm & 21.1 & 15.3 & 1.4 & 72 \\
\hline & & Membrane & 9.4 & 3.1 & 3.06 & 32 \\
\hline & \multirow[t]{3}{*}{$\mathrm{MB}$} & Extract & 31.2 & 36.6 & 0.85 & 100 \\
\hline & & Cytoplasm & 5.6 & 21.5 & 0.26 & 18 \\
\hline & & Membrane & 27.1 & 10.8 & 2.51 & 87 \\
\hline & \multirow[t]{3}{*}{$\mathrm{H}^{+}$} & Extract & $<0.02$ & 22.7 & $<0.001$ & - \\
\hline & & Cytoplasm & $<0.01$ & 15.3 & $<0.001$ & - \\
\hline & & Membrane & $<0.003$ & 3.1 & $<0.001$ & - \\
\hline \multirow[t]{3}{*}{$\mathrm{H}_{2}$ oxidation } & \multirow[t]{3}{*}{$\mathrm{NADP}^{+}$} & Extract & 213.5 & 22.7 & 9.4 & 100 \\
\hline & & Cytoplasm & 98 & 15.3 & 6.4 & 46 \\
\hline & & Membrane & 54 & 3.1 & 17.5 & 25 \\
\hline
\end{tabular}

\section{Discussion}

Strain FIGlyR was isolated in pure culture with glyoxylate as sole carbon and energy source from the syntrophically glycolate-degrading coculture FlGlyM. Although strain FlGlyR could not be transferred into pure culture from a single cell clone, the syntrophic methanogenic partner bacterium was diluted out of the culture by repeated transfers in the presence of the inhibitor 2-bromoethanesulfonate. Lack of growth in agar cultures may be due to accumulation of inhibitory $\mathrm{H}_{2}$ concentrations (see below). A similar problem was reported also for the syntrophically butyrate-degrading bacterium Syntrophus buswellii, which grows in pure culture with crotonate only in liquid medium, but not in agar (Dörner 1992). Growth and isolation of strain FlGlyR with glyoxylate in pure culture prove again that the concept of obligate syntrophy has to be revised. Recently, other strains formerly regarded as obligate syntrophs, such as Syntrophomonas wolfei, Syntrophospora bryantii, Syntrophobacter wolinii, and Syntrophus buswelii, have been shown also to grow with partly oxidized substrates in pure culture (Beaty and McInerney 1987; Zhao et al. 1990; Dörner 1992; Wallrabenstein and Schink 1994; Wallrabenstein et al. 1994).

Strain FlGlyR dismutated glyoxylate to glycolate, $\mathrm{CO}_{2}$, and $\mathrm{H}_{2}$, approximately according to the following equation:

$$
12 \text { glyoxylate } \rightarrow 7 \text { glycolate }{ }^{-}+3 \mathrm{H}_{2}+10 \mathrm{CO}_{2}(\mathrm{~g})
$$

$\Delta \mathrm{G}^{\circ \prime}=-29.3 \mathrm{~kJ}$ per mol glyoxylate

Glycolate was used for growth only in coculture with a hydrogen scavenger (Friedrich et al. 1991).
Biochemistry

The pathway of glyoxylate degradation by strain FlGlyR was elucidated by analysis of key enzymes (Fig. 5). Glyoxylate was oxidized via the malyl-CoA pathway (i.e., via malyl-CoA lyase and malate:CoA ligase and malic enzyme and pyruvate synthase. All these enzymes were detected at activities comparable to those of cells grown syntrophically with glycolate (Table 2; Friedrich et al. 1991). Membrane-bound glycolate dehydrogenase was also demonstrated at activities in the same range as those of syntrophically grown cells. In the pure culture, this enzyme obviously catalyzed glyoxylate reduction to glycolate. The stoichiometry of glyoxylate fermentation (Eq.1) revealed that a major part of reducing equivalents from glyoxylate oxidation served as electron donor for glyoxylate reduction to glycolate; only $12-27 \%$ were liberated as $\mathbf{H}_{2}$, depending on the initial glyoxylate concentration (Table 1).

Reversibility of the glycolate dehydrogenase reaction was demonstrated with membrane vesicles: glyoxylate was reduced with hydrogen as electron donor, probably involving electron transport from hydrogenase to glycolate dehydrogenase with menaquinones as electron carriers. The latter were previously found in glycolate- and glyoxylate-grown cells, but direct evidence of their participation in electron transport has not yet been obtained (Friedrich and Schink 1993). NADPH was tested as an alternative electron donor for glyoxylate reduction. Photometric analysis revealed an apparently glyoxylate-dependent NADPH oxidation, but this activity was not confirmed in attempts to measure NADPH-dependent glyoxylate conversion to glycolate by HPLC. Thus, direct reoxidation of NADPH with glyoxylate as electron acceptor seems unlikely. Nevertheless, some of the electrons from malic enzyme reaction end up in glyoxylate reduction to 
Fig.5 Hypothetical pathway of glyoxylate degradation by strain FlGlyR

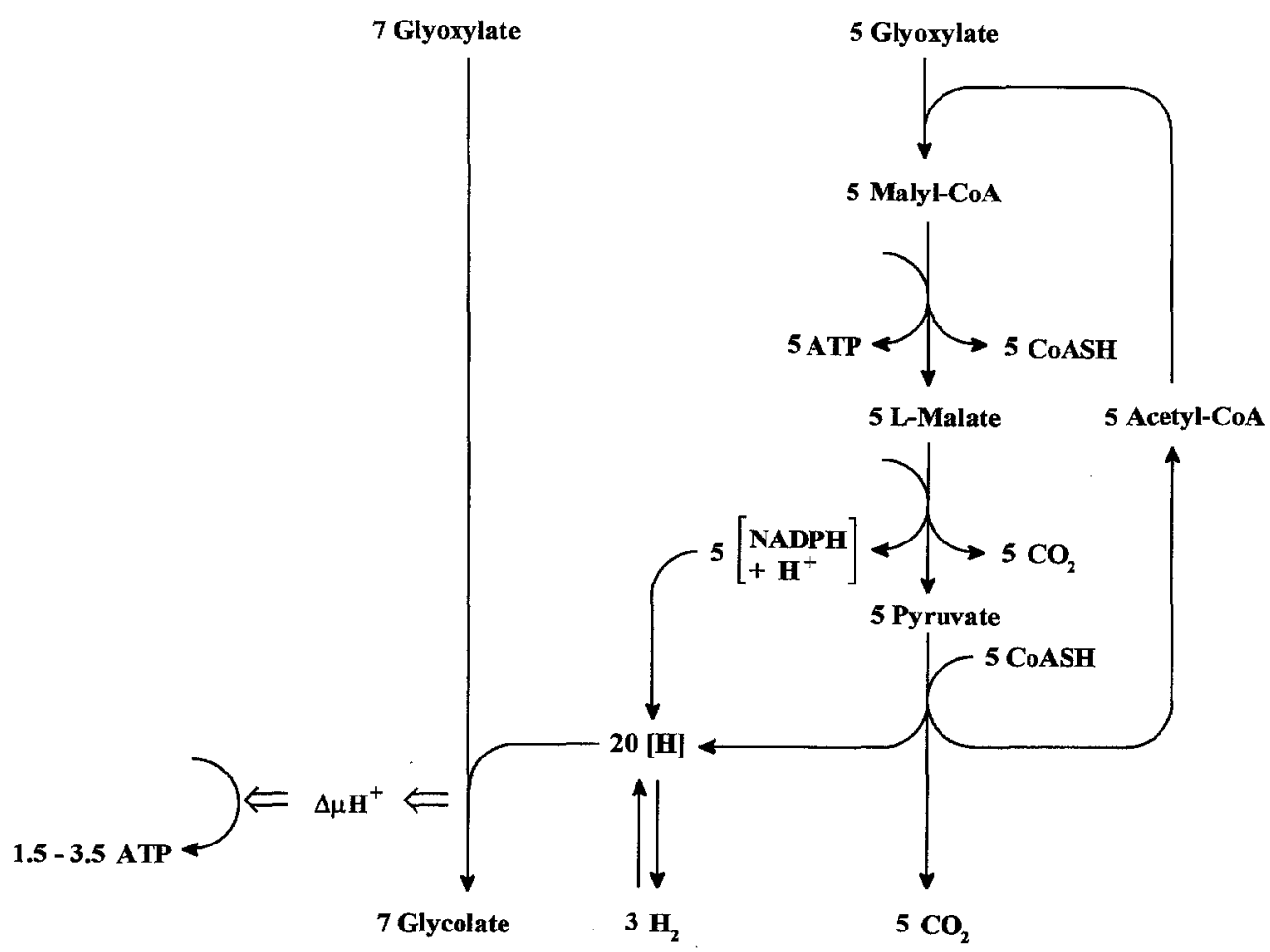

glycolate, as indicated by the fermentation balance. So far, the path of these electrons is still unknown, but $\mathrm{H}_{2}$ might be an intermediate, as suggested by the following findings, NADPH-oxidizing activities with benzyl viologen and methylene blue, and high activities of $\mathrm{H}_{2}$-dependent $\mathrm{NADP}^{+}$reduction were both found to be partly membrane-associated. A possible link of NADPH to the $\mathrm{H}_{2}$ pool $\left(\mathrm{E}^{\prime}=-353 \mathrm{mV}\right.$ at $\mathrm{P}_{\mathrm{H}_{2}}$ of $\left.1,000 \mathrm{~Pa}\right)$ would interfere directly with the malic enzyme reaction $\left[\mathrm{E}^{\circ-}=-331 \mathrm{mV}\right.$ calculated with $\mathrm{CO}_{2}(\mathrm{~g})$ after Thauer et al. 1977]. The $\mathrm{P}_{\mathrm{H}_{2}}$ did not exceed 1,000 Pa during growth of strain FlGlyR, even with increased glyoxylate concentrations, and strain FIGlyR was unable to grow with glyoxylate $(5 \mathrm{mM})$ in the presence of excess $\mathrm{H}_{2}(80 \mathrm{kPa})$. Obviously, reduction of the $\mathrm{NADP}^{+}$pool by excess $\mathrm{H}_{2}$ prevents malate oxidation and thereby inhibits glyoxylate fermentation. This may also be the reason why the pure culture of strain FlGlyR did not grow in agar cultures (see above).

We have shown previously that membrane vesicles of glyoxylate-grown cells catalyzed ATP-dependent $\mathrm{H}_{2}$ for-

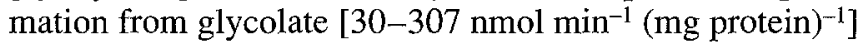
(Friedrich and Schink 1993). Now we demonstrate ATP formation due to glyoxylate reduction with $\mathrm{H}_{2}$ in membrane vesicles at a comparable rate. The $\mathrm{F}_{1} \mathrm{~F}_{0}$-ATPase inhibitor DCCD abolished glyoxylate reduction-driven ATP formation almost entirely (94\% inhibition, Table 3). In addition, we have shown previously DCCD inhibition of ATPase activity (Friedrich and Schink 1993). Glyoxylate reduction with hydrogen was influenced by DCCD only to a minor extent ( $32 \%$ inhibition; Table 3 ). It is well known that DCCD also interferes with several other proteins of bioenergetic relevance, such as cytochrome- $c$ oxidase, ubiquinol : cytochrome- $c$ oxidoreductase, NADH : ubi- quinone oxidoreductase, and energy-linked transhydrogenases due to its reactivity with carboxyl residues (Hassinen and Vuokila 1993); this might be a rationale for the observed $30 \%$ inhibition of $\mathrm{H}_{2}$-dependent glyoxylate reduction by DCCD. Nevertheless, ATP formation was already inhibited to a large extent, whereas glyoxylate was still reduced with $70 \%$ remnant activity, indicating involvement of proton-translocating ATPase. In addition, protonophores such as CCCP, SF 6847, and TCS also inhibited ATP formation. With the exception of TCS at concentrations higher than $10 \mathrm{nmol}$ (mg protein) ${ }^{-1}$, glyoxylate reduction was not affected by these protonophores. Interference of TCS with targets other than the proton-motive force has only recently been reported for luciferase (Peinemann et al. 1989). We conclude that ATP was formed from ADP and $\mathrm{P}_{\mathrm{i}}$ by a proton-translocating ATPase, probably of the $\mathrm{F}_{1} \mathrm{~F}_{0}$-type; this reaction was driven by a proton-motive force generated by the electron transport from glyoxylate to glycolate with $\mathrm{H}_{2}$ as electron donor. This electron transport phosphorylation represents the reversal of the reversed electron transport from glycolate to glyoxylate and $\mathrm{H}_{2}$ that was found recently in syntrophic glycolate oxidation (Friedrich and Schink 1993).

\section{Energetics}

Synthesis of ATP from ADP and $P_{i}$ under quasi-reversible conditions requires a minimum of $-44 \mathrm{~kJ}$ per mol in a living cell (Thauer et al. 1977), and irreversible ATP synthesis consumes up to $-70 \mathrm{~kJ}$ per mol (Schink 1991). Under standard conditions, glyoxylate respiration with $\mathrm{H}_{2}$ as electron donor is sufficiently exergonic $\left(\Delta \mathrm{G}^{\circ}=-62\right.$ $\mathrm{kJ}$ per mol glyoxylate) to drive electron-transport-linked 
synthesis of one ATP per glyoxylate reduced, and we showed ATP synthesis under comparable conditions with everted membrane vesicles. A stoichiometry of $0.2-0.5$ ATP synthesized per glyoxylate reduced was deduced from rates of ATP formation and glyoxylate reduction, indicating that ATP synthesis and glyoxylate respiration were not strictly coupled. This may be due to the membrane vesicle preparation used that might have consisted of everted vesicles, right-side-out vesicles, and open membrane fragments; phosphorylation is expected to be carried out only in everted vesicles (Kröger and Winkler 1981). Glyoxylate fermentation by strain FlGlyR according to Eq. 1 yields $-29 \mathrm{~kJ}$ per mol glyoxylate. Under physiological conditions (i.e., $1.5 \mathrm{mM}$ glyoxylate, $1.5 \mathrm{mM}$ glycolate, $30 \mathrm{mM} \mathrm{HCO}_{3}$, and $600 \mathrm{~Pa} \mathrm{H}_{2}$ ), growth with glyoxylate according to Eq. 1 yields $-73 \mathrm{~kJ}$ per mol glyoxylate. According to the reaction sequence outlined in Fig. 5, $0.4 \mathrm{~mol}$ ATP per mol glyoxylate is synthesized by substrate level phosphorylation, and $0.13-0.3 \mathrm{~mol}$ ATP per mol glyoxylate by glyoxylate respiration based on the phosphorylation stoichiometry measured with membrane vesicles. The overall ATP gain of 0.5-0.7 mol ATP per mol glyoxylate metabolized is in good agreement with $\mathrm{Y}_{\mathrm{s}}$ of $4.6-5.7 \mathrm{~g}$ per mol glyoxylate measured, assuming that $10 \mathrm{~g}$ cell dry matter is formed per mol ATP (Stouthamer 1979). Glyoxylate fermentation by strain PerGlyox 1 originally isolated with glyoxylate as substrate yielded only $1.8 \mathrm{~g}$ per mol glyoxylate, although glyoxylate was degraded via the same pathway (Table 1; Friedrich and Schink 1991). The difference in yield is probably due to the inability of strain PerGlyox 1 to conserve energy by glyoxylate respiration. Instead, a small amount of glycolate (1 glycolate per 4 glyoxylate) is formed by an NADH-dependent glyoxylate reductase, and ATP is synthesized only by substrate level phosphorylation (Friedrich and Schink 1991). This strain cannot oxidize glycolate syntrophically, and the glycolate dehydrogenase reaction operates only toward glycolate formation. Glyoxylate respiration in strain FlGlyR contributes to energy conservation, and this strain grows obviously closer to thermodynamic equilibrium than strain PerGlyox1 in which glycolate reduction only increases the reaction entropy. The possible advantage of the latter strategy still needs to be elucidated.

The phylogenetic status of strain FlGlyR will be defined in detail in a forthcoming study based on 16S rRNA sequence analysis. Strain FlGlyR has been deposited with Deutsche Sammlung von Mikroorganismen, Braunschweig, Germany, under no. DSM 8271.

Acknowledgements This work was supported by the Bundesministerium für Forschung und Technologie, Bonn (Biologische Wasserstoffproduktion). We thank Dr. P. H. Janssen (Marburg, Germany), and Dr. A. Brune (Konstanz, Germany) for valuable discussions.

\section{References}

Beaty PS, McInerney MJ (1987) Growth of Syntrophomonas wolfei in pure cultures on crotonate. Arch Microbiol 147:389-393
Bradford MM (1976) A rapid and sensitive method for the determination of microgram quantities of protein utilizing the principle of protein-dye binding. Anal Biochem 72:248-254

Diekert GB, Thauer RK (1978) Carbon monoxide oxidation by Clostridium thermoaceticum and Clostridium formicoaceticum. J Bacteriol 136:597-606

Dörner C (1992) Biochemie und Energetik der Wasserstoff-Freisetzung in der syntrophen Vergàrung von Fettsäuren und Benzoat. Ph.D. thesis, Universität Tübingen, Germany

Friedrich M, Schink B (1991) Fermentative degradation of glyoxylate via malyl-CoA by a new strictly anaerobic bacterium. Arch Microbiol 156:392-397

Friedrich M, Schink B (1993) Hydrogen formation from glycolate driven by reversed electron transport in membrane vesicles of a syntrophic glycolate-oxidizing bacterium. Eur J Biochem 217: 233-240

Friedrich M, Laderer U, Schink B (1991) Fermentative degradation of glycolic acid by defined syntrophic cocultures. Arch Microbiol 156:398-404

Hassinen IE, Vuokila PT (1993) Reaction of dicyclohexylcarbodiimide with mitochondrial proteins. Biochim Biophys Acta 1144: 107-124

Kröger A, Winkler E (1981) Phosphorylative fumarate reduction in Vibrio succinogenes: stoichiometry of ATP synthesis. Arch Microbiol 129:100-104

Linnett PE, Beechey RB (1979) Inhibitors of the ATP synthase system. Methods Enzymol 55:472-518

Litters N, Schmelzeisen-Redeker G (1989) Experience with fast HPLC in the routine analytical laboratory. GIT Fachz Lab 33: $81-83$

Mesbah M, Premachandran U, Whitman WB (1989) Precise measurement of the $\mathrm{G}+\mathrm{C}$ content of deoxyribonucleic acid by high-performance liquid chromatography. Int J Syst Bacteriol 39: 159-167

Odom JM, Peck HD (1981) Localization of dehydrogenases, reductases and electron transfer components in the sulfate-reducing bacterium Desulfovibrio gigas. J Bacteriol 147:161-169

Peinemann S, Blaut M, Gottschalk G (1989) ATP synthesis coupled to methane formation from methyl-CoM and $\mathrm{H}_{2}$ catalyzed by vesicles of the methanogenic bacterial strain Göl. Eur J Biochem 186:175-180

Platen H, Schink B (1987) Methanogenic degradation of acetone by an enrichment culture. Arch Microbiol 149:136-141

Schink B (1991) Syntrophism among prokaryotes. In: Balows A, Trüper $\mathrm{HG}$, Dworkin $M$, Harder W, Schleifer KH (eds) The prokaryotes, 2nd edn. Springer, Berlin Heidelberg New York, pp 276-299

Stams AJM, Kremer DR, Nicolay K, Weenk GH, Hansen TA (1984) Pathway of propionate formation in Desulfobulbus propionicus. Arch Microbiol 139:167-173

Stouthamer AH (1979) The search for correlation between theoretical and experimental growth yields. Int Rev Biochem $21: 1-47$

Thauer RK, Jungermann K, Decker K (1977) Energy conservation of chemotrophic anaerobic bacteria. Bacteriol Rev $41: 100-180$

Vogel G, Steinhart R (1976) ATPase of E. coli: purification, dissociation and reconstitution of the active complex from the isolated subunits. Biochemistry $15: 208-216$

Wallrabenstein C, Schink B (1994) Evidence of reversed electron transport in syntrophic butyrate or benzoate oxidation by Syntrophomonas wolfei and Syntrophus buswellii. Arch Microbiol $162: 136-142$

Wallrabenstein C, Hauschild E, Schink B (1994) Pure culture and cytological properties of "Syntrophobacter wolinii." FEMS Microbiol Lett 123:249-254

Widdel F, Pfennig N (1984) Dissimilatory sulfate- or sulfur-reducing bacteria. In: Krieg NR, Holt JG (eds) Bergey's manual of systematic bacteriology, 9th edn, vol 1. Williams \& Wilkins, Baltimore, pp 663-679

Zhao H, Yang D, Woese CR, Bryant MP (1990) Assignment of Clostridium bryantii to Syntrophospora bryantii gen. nov., comb. nov., on the basis of a 16S rRNA sequence analysis of its crotonate grown pure culture. Int J Syst Bacteriol $40: 40-44$ 